\title{
Study on College English Teaching Based on the Concept of Ideological and Political Education in All Courses
}

\author{
Feipeng Li, Huijun Fu \\ College of Foreign Languages Education and International Business, Baoding University, Baoding, China \\ Email: lfp19801104@163.com
}

How to cite this paper: Li, F, P., \& Fu, H. J. (2020). Study on College English Teaching Based on the Concept of Ideological and Political Education in All Courses. Creative Education, 11, 997-1007. https://doi.org/10.4236/ce.2020.117072

Received: May 25, 2020

Accepted: July 10, 2020

Published: July 13, 2020

Copyright $\odot 2020$ by author(s) and Scientific Research Publishing Inc. This work is licensed under the Creative Commons Attribution International License (CC BY 4.0).

http://creativecommons.org/licenses/by/4.0/

\section{(c) (i) Open Access}

\begin{abstract}
Ideological and political theory teaching in all courses is an essential requirement and growing tendency of ideological and political education in colleges and universities under new circumstances, the core of which is to explore the ideological and political elements and organically integrate them into different disciplines and courses. With prominent characteristics of instrumentalism and humanism, college English is an important platform for ideological and political theory teaching, which possesses its own unique and huge advantages. Based on the concept of ideological and political education in all courses and aimed at cultivating talents with political integrity and professional competence, this paper discusses the feasibilities of college English teaching with ideological and political education and explores effective ways to realize the idea of "from courses of ideological and political teaching to courses for ideological and political teaching" in college English course from the perspectives of teachers, students, teaching systems, teaching contents and instructional evaluations.
\end{abstract}

\section{Keywords}

College English Teaching, Ideological and Political Education in All Courses, Feasibility, Ideological and Political Elements, Implementation Strategies

\section{Introduction}

General Secretary Xi Jinxing pointed out in the National Conference on Ideological and Political Work of Colleges and Universities in December 2016 that morality education should be regarded as the central link; it is required that ideological and political work be carried out in the whole possess of education 
and teaching to realize "whole-process and all-round education"; all kinds of courses should be developed in the same direction with ideological and political theory courses to achieve the effect of synergy (Xi, 2016). Universities in Shanghai such as Shanghai International Study University and Shanghai University have implemented a series of projects on "ideological and political theory teaching in all courses" since 2014 and obtained significant achievements. The so-called "ideological and political theory teaching in all courses" is a new concept and model of ideological and political work in college that digs into the educational values of all types of courses from the perspective of education, and for the most part exerts ideological and political education resources of different courses in order to promote students' ethical standard, political consciousness, mortal character and cultural literacy (Lu, 2019). As one of the public basic courses for general education, college English course takes up more hours and has broad student coverage, the textbook contents of which complies with the principles of ideological and political teaching. For the purpose of cultivating firm believers, active disseminators and model practitioners of socialist core values, this paper explores effective ways to integrate ideological and political theory teaching into college English course from the perspectives of teachers, students, teaching systems, teaching contents and models of evaluation.

\section{Theoretical Basis}

\subsection{Holistic Education}

First put forward by American educator Ron Miller in the 1970s, holistic education is a new educational concept that integrates two previous viewpoints on education-"people-oriented" and "society-oriented", attaching importance both to the values of society and humans (Miller, 1988). According to humanistic education theory, real learning experience enables learners to find out their unique qualities and characters. In this sense, to learn means to "become" because to become an impeccable person is the only true study. Holistic education, in a sense, is the education for cultivating the "whole man" or "perfect man" (Wen, 2014). According to the Guidance for College English Teaching, "College English has the quality of instrumentalism and humanism. The core of humanism is people-oriented, emphasizing the cultivation of people's comprehensive qualities and integrated development." As a significant component of ideological and political theory teaching, the organic integration of socialist core values into college English teaching contents is required. Therefore, the rich humanistic connotation of college English course needs to be fully excavated, thus realizing the skillful integration of its instrumental and humanistic characteristics.

\subsection{Penetration Theory}

The penetration theory of ideological and political education is an essential section of the theoretical system of ideological and political education. It is the penetration activities of the ideological and political teaching that serve as crucial 
approaches to promoting the effectiveness of ideological and political education. The penetration of ideological and political education is that the contents of ideological and political education are integrated into the mind of the instructional objects though various ways under certain circumstances by educators (Liu, 2008). The content of penetration covers not only the theoretical knowledge of Marxism but also traditional virtues, civic moralities and socialist core values as well. The educational penetration of ideology and politics, as an all-round and multi-dimensional activity, exists throughout the whole process of people's ideological and moral cultivation beyond restriction of time and space. With its unique characters and advantages, college English course is obliged to shoulder the responsibility to develop students' ideological and political level though educational penetration.

\section{Feasibility Analysis on College English Teaching Based on the Concept of Ideological and Political Education in All Courses}

The National Outline of Medium and Long-term Education Reform and Development Program (2010-2020) points out that college and universities should focus on cultivating top-quality professional talents with persistent faith, good morality, rich knowledge and excellent skills. The Guidance for College English Teaching (the Guidance for short), putting forward instructional proposals to college English teaching, becomes a new basis and standard for college English curriculum construction and teaching activities. Not only can these courses strengthen the national cultural confidence, expand the international influence and attraction of Chinese culture, but they can also promote students' understanding, respect and tolerance for exotic cultures, help students to establish correct cultural viewpoint and advance Sino-foreign cultural exchange and cooperation.

\subsection{Feasibility Analysis from the Contents of College English Teaching}

As for basic contents of college English teaching, the Guidance advises colleges and universities to offer three main curriculum modules including English for general purpose, English for specific purpose and inter-cultural communication. Besides instrumentalism, all the three curriculum modules should reflect the humanism feature of language development. English for general purpose needs to cultivate students' patriotism, international horizon, humanist spirits, logical thinking ability, cooperation ability and so on. English for specific purpose also makes demand for students' understanding and expressing ability of academic spirit, academic integrity, professional ethics and cultural values. Enhancing student's inter-cultural communication ability in English, inter-cultural communication course, with its humanistic quality, is aimed at helping students to learn about the differences between China and other countries in worldviews, values and ways of thinking, and cultivating their cross-cultural awareness. Textbooks 
are the essential carriers of teaching contents. The reform of college English textbooks has been progressing with the times. The 2017 edition of New Progressive College English is one of the typical text books that incorporate ideological and political education to students. The materials of this textbook attach specific importance to the reflection of Chinese elements with a China-related passage in each unit, which has taken a further step in the reform of college English textbooks. The diversification of teaching materials will provide sufficient guarantees for the practice of ideological and political education in college English teaching.

\subsection{Feasibility Analysis from the Functions of College English Teaching}

The Guidance for College English Teaching defines the function of humanism as well as instrumentalism of improving students' English skills. The core of humanism is to be people-oriented, to carry forward human value, to emphasize the cultivation of comprehensive qualities and all-round development. Therefore, it is required that the socialist core values be integrated into college English teaching, and the humanistic connotation of college English courses be fully explored. The Guidance makes it clear that college English teaching is an important component of higher education in China, and it is of great significance to promoting the coordinated development of students' knowledge, ability and overall quality. College English plays an irreplaceable role in talents cultivation, so it needs to embody the whole value of higher education. It is no doubt that English learning can prompt students to learn culture and knowledge, broaden their international horizons, thus truly reflecting the educational function of college education. It is the potential educational function of college English course that provides the basis and possibility for "ideological and political theory teaching in all courses".

\subsection{Feasibility Analysis from the Characters of College English Teaching}

College English is a basic compulsory course for all the non-English majors in colleges or universities, which has been playing an indispensible role in the cultivation of qualified socialist construction talents. College English course has its unique features compared with other courses in the teaching objects, teachers, class hours, academic years, etc. Firstly, as a public course, college English is one of the most widely students' covered courses in universities. Secondly, college English has comparatively longer-term schooling and more class time, with four academic semesters and two to four classes each week, thus ensuring the continuity and systematicness of education. Thirdly, college English teachers should take the opportunity of teaching western language culture and make the best use of the circumstances to strengthen students' confidence in national cultures though the comparison of cultural differences between China and western countries, thus cultivating the believer, practitioner and disseminator of socialist core values. 


\section{Implementation Strategies on College English Teaching Based on the Concept of Ideological and Political Education in All Courses}

With its main qualities and advantages discussed above, college English should serve as an important channel and frontier of implicit ideological and political education to students. Teaching strategies on ideological and political theory education in college English course are required to be implemented from different perspectives.

\subsection{Integrating Ideological and Political Elements by Innovating Teaching Contents}

Firstly, rationalize the use of existing textbooks. Taking inter-cultural communication textbooks for example, they not only introduce the basic concepts of language and culture and theories of cultural values, but also present typical Chinese and foreign cases through various forms such as pictures, texts, audios and videos. As national textbook for the Twelfth Five-year Plan, "College English Course Book of Cross-Cultural Communication" is aimed at guiding students to actively cognize, analyze, compare and evaluate cultures and cultural differences, enabling them to obtain an objective, systematical and overall understanding of western cultures, thus broadening students' international horizons, promoting their cross-cultural consciousness and critical spirits.

Secondly, update and improve textbooks of college English for general purpose. The newly-added question type "Chinese-English Translation" in the reform of CET4 in 2013 involves politics, economy, society and culture. The reform reflects the deficiency of ideological and political education in college English teaching and realistic demand for college English teaching, and becomes the guide of college English textbook compiling. "New Horizon College English Reading and Writing" (3rd Edition, Foreign language Teaching and Research Press) keeps abreast of the times and integrates elements including Chinese politics, economy, society and traditional cultures, performing its implicit functions in ideological and political education. Supported by the online platform of Unipus, Foreign language Teaching and Research Press is working on forging "one-stop" solutions for moral education with the mixtures of textbooks, digital course for reading and writing with ideological and political education and digital resources for ability development. While most of the college English teaching materials choose articles mainly from foreign journals or western literatures that reflect western ideas on values and mainstream ideology. More college English textbooks that embodies Chinese elements and advocate socialist core values are required to designed and compiled.

Thirdly, compile school-based textbooks which accord with national and school conditions and characteristics of the new age. Xi Jinping pointed out that "To do a good job in college ideological and political education, we need to change with new cases, advance with the times, innovate with tendencies." 
Therefore, in order to target and validate the ideological and political education to college students, the compiling of school-based textbooks should incorporate current events, the times, national policies, and school culture construction. It is advocated that more policy support should be implemented on the college and universities that explore school-based teaching materials for college English.

Apart from developing students' ability of language, college English education takes the responsibility and obligation to improve students' personality, emotion and their life-long learning ability. The contents choice, organization, presentation and evaluation of college English textbooks, explicit or implicit, inevitably carries and transmits some kind of cultural ideology and value orientation. Keeping conscious cognition to that, the editors and readers of college English textbooks should scientifically and rationally compile teaching materials and implementing education based on the principle of critical assimilation.

\subsection{Establishing Dynamic System of Ideological and Political Education in College English Course}

College English educators should be clear about the connotation and requirements of ideological and political theory education in all courses from the level of national development and construction and they must figure out three core issues: For whom to cultivate, how to cultivate, what kind of person to cultivate. College English teachers and school administrators need to establish system framework surrounding teaching aim and plan, teaching design, teaching implementing and teaching, thus performing concrete and dynamic education and teaching reform and research. The characteristics of the times and openness of ideological and political education contents continuously inject new vitality to college English course. All the essential links are interrelated and interacted so as to form the dynamic system of ideological and political education in college English course which is presented by the following diagram:

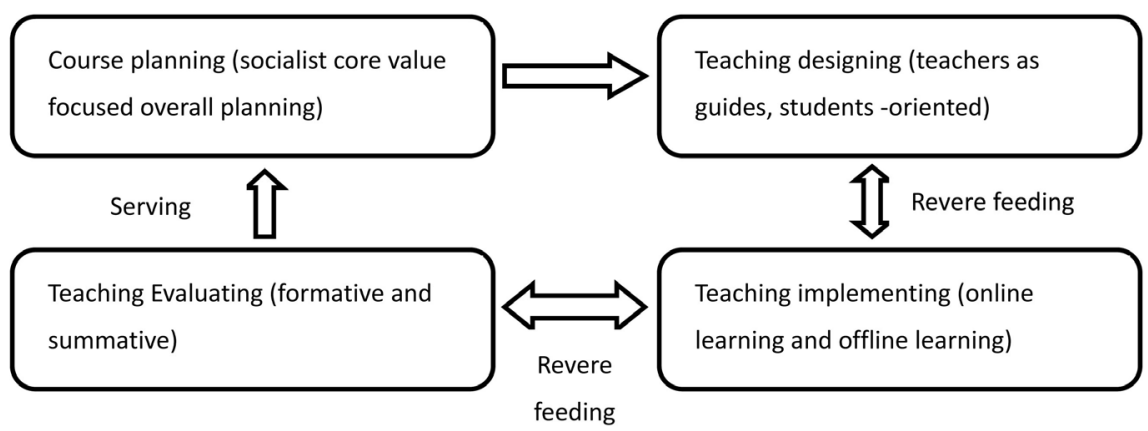

The dynamic system framework of ideological and political education in college English establishes the top-level design and becomes the development program of the course. The in-depth integrative exploring practice should be carried out from the aspects of extracting ideological and political elements, exploring and utilizing ideological and political resources, instructional design, the dominant role of teachers, the construction of textbook system, the optimizing of cur- 
riculum system and so on in order to guarantee the long-term mechanism of ideological and political education in college English course.

In the link of "Course planning", the aim of values should be firstly taken into consideration, including the cultivation of socialist core values, college talents training objectives and curriculum objectives. The ideological and political education elements require excavated and extracted. For example, the socialist core values are composed of three levels: the level of country covers transmitting advanced age culture and excellent traditional culture, manifesting the great achievements of socialist construction from the aspects of economy, politics, scientific technology and strengthen national self-respect and pride; the level of society includes pursuing a free, equal, impartial and law-based society, constructing harmonious, civilized and beautiful living environment, etc.; the level of individuals contains cultivating students' creation spirit, gratitude attitude, win-win thinking and independence, and carrying out "three-outlook education" students. The aim of values determines the direction of the course, so teachers need to make course planning closely around this aim. The course planning includes time distribution, course schedule, teaching and learning evaluation format and so on. As to the character and objectives, college English course is aimed at not only developing students' humanistic qualities, but also spreading China's voice and telling China's story. Language is the carrier of culture, so inheriting splendid traditional culture of China and spreading socialist culture with Chinese characteristics is a important mission of college English education.

How to incorporate ideological and political education elements into college English course is a problem which needs to be solved in the link of teaching design and implementation. It is advised that the link of teaching design be practiced by virtue of high-quality cyber resources like Coco English, MOOC, TED Talks, VOA, BBC, China Daily and Learning Power, from which different English learning corpus of text resources, audio and video resources are handpicked with various topics such as traditional and modern cultures, economy, scientific technology, politics and "three outlooks" education.

In the enacting link of ideological and political education in college English course, multi-mechanism strategies and approaches to teaching should be adopted from teaching operation, teaching regulation, education subjects and teaching channels so as to guarantee the valid implementation of ideological education. Another point that requires attention is to adjust teacher-student relationship and to emphasize the development of students' learning subjectivity. Teachers must believe in the creativity of students without a shadow of doubt. To achieve this, teachers should become students' cooperative partners in the association with students (Paulo, 2009). The learning subjectivities of students are reflected from various links in teaching and learning including the setting of objectives and choosing of learning contents and learning methods. The whole learning course should be a learning, reflecting and cooperative process where learners can study with self-regulations.

Meanwhile, it is suggested that teachers pay more attention to the cultivation 
of students' autonomous learning ability. With the limitation of class time and heavy language teaching tasks, how to make best use of the time after class to realize moral education to students is a crucial path to be closely considered. The best way of education is self-education. Teachers can design various assignments for students to accomplish after class and guide them to make utmost of the net recourse, thus realizing the extension of classroom teaching and learning and the development of student's learning initiative.

The evaluation of courses requires to be realized by diverse, scientific and effective approaches by both teachers and students. First, transform from summative assessment to the combination of summative assessment and formative assessment. Summative assessment just runs counter to the concept of holistic education, the goal of which is to develop critical thinking and innovation capacity, while formative assessment performs evaluation to learners from the perspective of outcome, attitude, emotion, communicative abilities and innovative capacities. Besides teacher assessment, other forms of assessment like peer assessment and self-assessment can be utilized to improve the development of learners' knowledge and skills, improve their emotion and attitude, strengthen their sense of responsibility and promote their abilities to find out questions, raise questions and resolve questions.

\subsection{Demand, Cultivation and Professional Development for College English Teachers}

First, transform teachers' educational concepts. Influenced by their major of English and traditional English teaching ideas, most college English teachers tend to pay more attention to the instruction of English knowledge and cultures and the cultivation of English skills such as listening, speaking, reading and writing. In the new age, however, English teachers are also required to advance with the times and realize that not only will ideological and political education in English class not interfere with English teaching activities and teaching efficiency, but conversely it also will helpfully contribute to promoting the ideology and humanity of English course and constantly deepening the teaching connotation. College English teachers should set up the core concept of "ideological and political education in all courses", fully realize the intrinsic and social value of the discipline, and strengthen the sense of educational mission and social responsibility. Teachers should be aware that the teaching process of college English itself is the principal course of education, and the knowledge instruction and value guidance are the basic realization forms of the educational function of college English course. In the teaching of college English, therefore, great importance should be attached both to expanding scope of knowledge in the course of value transmission and emphasizing value guidance in the course of knowledge instruction, which is the mutual combination of explicit language education and implicit morality education (Gao, 2017).

Second, establish a team with reasonable teacher structures, outstanding teaching qualities and excellent research abilities. Teachers are the key power to im- 
plement "ideological and political theory teaching in all courses". Reinforce the ideological and political work for college English teachers and improving their moral attainment are the crucial guarantee for enacting "ideological and political theory education in all courses". Therefore, college English teachers and ideological and political theory teachers should set up teaching and research team, and conduct operation, communication and mutual learning in making of teaching objectives, planning for teaching contents, design for teaching methods and implementation of teaching assessment. Only in this way can the ideological and political contents be effectively infiltrated into college English textbooks. From the above, college English teachers are required to establish the ideas of "generalized ideology and politics". Meanwhile, it is necessary for ideological and political theory teachers to give lectures on the hot issue about ideology and politics or cultural qualities. Great efforts should be done to promote ideological and political levels and conscience.

With the emphasis on the ideological and political education in college English course, a series of relevant training sessions have been held by some universities that have implemented moral education in English course and done lots of research in this field. Relying on the platform of Unipus constructed by Foreign Language Teaching and Research Press, a secession of online and offline lectures and training courses have been provided for college English teachers with broad coverage of topics including Moral Education in English Teaching: Concept and Practice, by Professor Yang Luxin, from Foreign Language Teaching to Foreign Language Education, by Professor Tian Zhaoxia, Teaching Design and Materials Digging of Moral Education in College Foreign Language, by the teaching team from Tianjin University of Commerce and Yantai University.

Xi Jinping pointed out that teachers should make good use of classroom and school, and advocate socialist core values with self-actions, kindle students' yearning for truth, kindness and beauty with their knowledge, career and experience. It is demanded that college English teachers not only grasp discipline knowledge, English teaching methods and linguistic knowledge, but also master extensive humanistic and psychological knowledge, understand the "Basic Tenets of Marxism", "Ideological and Moral Cultivation and Legal Basis" and "Situation and Policy". Only when teachers themselves reach high level can students' realm of thought get improved.

\section{Conclusion}

University is the main position where the constructers and successors of socialism with Chinese characteristics are cultivated. The construction of ideological and political theory teaching in all courses has become an inevitable demand of the new age. As an important compulsory course in majority of universities, college English possesses its unique characteristics and advantages in ideological and political education compared with other curriculums. College English teachers not only take the responsibility to instruct language knowledge, but shoulder the mission of education and cultivation as well. The mutual integration of college 
English teaching and the ideological and political education is a requisite measure to realize the overall development of students and foster virtue through education. Therefore, college English teaching with ideological and political education can build a dense atmosphere for all-rounded cultivation, thus powerfully enhancing the ideological and political education for college students and boosting students' overall development.

Based on what has been discussed and found in the paper, various practical strategies and measures can be taken to realize the ideological and political education during the process of college English teaching. From the perspective of college English teachers, they are required to deeply excavate the ideological and political elements in teaching materials and contents and adopt diverse and flexible approaches to conducting integrated quality education with abundant practical activities. The training of ideology and politics theories and new media technologies to college English teachers also cannot be ignored. It is advisable that English teachers strengthen cooperation and communication with teachers of ideological and political theory course, even explore new teaching mode of classroom "co-teaching". Another matter which needs attention is that the ideological and political education in English class should be conducted based on college English teaching materials and contents. Meanwhile, systematic teaching and learning evaluation should be scientifically designed and enacted. For example, students' performances in accomplishing tasks concerning related subjects can be added to students' formative assessment. The testing materials and question-designing guidance can be appropriately adjusted to the ideological and political education. With all these strategies and ways students will not only acquire language knowledge but also get improved in their capacity of intercultural communication. Under the guide of ideological and political education in English course, students can promote their ability to critically absorb western cultures and identify more clearly about the cultural differences between different nations, and eventually become high-quality talents with solid language knowledge and skills and excellent moral characters.

\section{Funding}

The thesis is the research result of Humanistic and Social Science Research Project of Hebei Colleges and Universities: Study on the Strategies of Ideological and Political Theory Teaching in College English Course Based on Teaching Process Optimization Theory. Project number: GH202012.

\section{Conflicts of Interest}

The authors declare no conflicts of interest regarding the publication of this paper.

\section{References}

Gao, Y. (2017). On Practicality of College English Class Becoming the Front of Ideological and Political Education in College and Universities. Education Teaching Forum, 
No. 28, 28-29.

Liu, X. G. (2008). Methodology of Modern Ideological and Political Education (p. 145). Beijing: People's Publishing House.

Lu, G. P. (2019). An Effective Exploration of Integrating Ideological and Political Education into College English Curriculum. Journal of Shanghai Polytechnical University, No. 2, 129-133.

Miller, J. P. (1988). Holistic Curriculum. Toronto: OISE Press, Inc.

Paulo, F. (2009). Pedagogy of the Oppressed. Bloomsbury: Bloomsbury Academic.

Wen, X. Y. (2014). The Realization of Holistic Education in Foreign Language Teaching. Foreign Language World, No. 5, 76-82.

Xi, J. P. (2016). Speech in the National Conference on Ideological and Political Work of Colleges and Universities.

http://www.xinhuanet.com/politics/2016-12/08/c_1120082577.htm 